\title{
CLASSIFICATION OF CHILDREN SHORT FILMS FOR MOBILE MOVIE SCREENING BY BIOSCIL
}

\author{
Lukas Deni Setiawan* and Birgitta Bestari Puspita \\ Universitas Atma Jaya Yogyakarta, Indonesia
}

\begin{abstract}
Access to movie is limited for some part of the society due to minimum amount of cinema in remote area or suburban. This limited access is worsen by the limitation of available children films. BIOSCIL (Bioskop Kecil Keliling), a community based organization, concerns about the situation and responds to it. BIOSCIL conducts mobile movie screening for children in remote areas in Yogyakarta. So far, they have at least visited 20 locations in five years. Together with several local movie makers, BIOSCIL tries to collect movies that can be watched by their audience in remote area. However, the limited amount of children movies brings new problem to BIOSCIL because not every movie in their inventory matches their audience in each screening. Thus, it is important to make movie classification for BIOSCIL based on their audience age group, to help them choose the right movie for each screening and audience. This is a participatory action research using FGD, documentary, and participatory observation for data collection. After working together with BIOSCIL for over a year, this research has successfully defined a movie classification for BIOSCIL to serve as a guideline for BIOSCIL to decide the right movie for their audience in each screening.
\end{abstract}

Keywords: Children movie, Film community, Movie classification, Remote area, Yogyakarta

\section{Introduction}

Indonesia has limited amount of cinemas which is not proportional if it is compared to its total area. Until 2018 with total population of more than 260 million people, Indonesia only has 196 cinemas, with 1.118 screens, and $87 \%$ of it are located only in Java and big cities (Widyanita, 2016). Those numbers show that many areas and some of Indonesian citizen have no access to cinema. In the context of children, it is worsen by the fact that at least in the last 90 years of national film production, the total amount of children films is not sufficient. In a year, less than one children film is produced in Indonesia. There is a huge gap between the amount of films for children and adult (filmindonesia.or.id, 2018).

Data from Film Censorship Department of the Republic of Indonesia since January 2017 until March 2018 shows that films for children are limited. Only around $10 \%$ of films that produced both nationally and imported during that period can be classified for all age groups (Rosalia, 2018). Meanwhile, one-third of Indonesia's total population in 2019 are children, who can be considered as the neglected target audience.

That data is aggravated by Hananta's research (2013) about three most popular children films which are screened in cinema in three years period. Those films are, "Meraih Mimpi" (2009), "Obama Anak Menteng" (2010), and "Lima Elang" (2011). Those popular films, which have been watched by many children in Indonesia, ironically contain many types of psychological violence, namely yelling, demeaning, insulting, reigning over, stalking, slandering, spying, and threatening.

The great concern about this limited access to the children films is responded uniquely by BIOSCIL (Bioskop kecil keliling). BIOSCIL is an independent activity founded by Rifqi Mansur Maya (Kiki) and Hindra Setya Rini (Hindra). This activity is based on two important objectives. First, children, wherever they are, must get the same access to information. Second, this access to information will not be meaningful when the quality of the content is not children friendly. At this point, these simple objectives of BIOSCIL meet the concern of national 
film production in Indonesia. BIOSCIL opens a small screening space in the remote areas in Yogyakarta which have limited access to cinema and diversity of films. In the last five years, BIOSCIL has reached at least 20 location with this mobile movie screening activity focusing on short films screening.

So far, the movie screening is conducted in elementary schools, houses, communities, and village meeting halls. Those places are transformed to be a simple small cinema during the time of movie screening. Children who have never been to the cinema can feel the atmosphere through the setting and screening activity. Same as in the cinema, children who walk into the room will feel ready to enjoy the movie.

When the access to the films has been opened for the children, BIOSCIL concerns about the suitable film for them. Good access will be useless without a good content. Thus, BIOSCIL searches for children films, which is not easy. It is mainly because not many film producers concern to this specific segment. BIOSCIL carefully chooses the films. They do not want to falsely choose the films about children which actually not dedicated for children.

Hence, it is an urgent needs for BIOSCIL to find the formula to classify the children short films because BIOSCIL keeps on receiving movie screening requests. Unfortunately, BIOSCIL faces problem in the classification process due to some reasons. First, this classification problem also happens in national movie business. Film Censorship Department of the Republic of Indonesia still prioritizes censorship than film classification system. Second, the policy of film classification is not well implemented in cinema. Third, the limited references on film classification in Indonesia. Based on BIOSCIL needs and the problems stated earlier, this research aims to help BIOSCIL identifying the criteria for children short films classification based on the age groups of their target audiences.

\section{Research question}

Based on BIOSCIL needs and the problems stated earlier, this research aims to answer the following question: What the most suitable short film classification guideline for BIOSCIL's mobile movie screening?

\section{Research objective}

This research aims to help BIOSCIL identifying the criteria for children short films classification based on the age groups of their target audiences.

\section{Research gap}

BIOSCIL wishes to have their own guideline to classify which short film is proper to be screened in front of children from a specific age range. This occurs because BIOSCIL often has to deal with specific problem of children from remote area, which is character difference from each area. Thus, a guideline to help them choosing the suitable short film for the children in specific area is an urgent needs.

However, that wish is hard to be realized since film classification in Indonesia is unpopular. Indonesian citizen cannot easily get the guideline for doing an independent film classification. Therefore, this research helps to further identify the problem and to help BIOSCIL developing the most suitable concept to independently formulate a classification guideline for their mobile movie screening activity.

\section{Conceptual frameworks}

The conceptual framework of this research is based on three main concepts. First, concept on children's cognitive development. Second, concept about movies classification. Third, concept about mobile movie screening. Those three concepts are used as guidance to identify and to analyze the data on children short films classification for BIOSCIL. 


\section{Children's Cognitive Development}

Children's cognitive development is an important concept in this research since this research is involving children's ability to receive information, which in this context is short films. In certain age group, children develop a certain cognitive ability. This research uses the concept from Jean Piaget, a psychologist, who had written many works on children's cognitive development. Piaget is also one of psychologists who could firmly divide children not only in a single age group, such as $0-17$ years old or $0-18$ years old.

According to Joubish and Khurram (2011), Piaget divided child's age group based on their cognitive development into four stages. First stage is Sensori-motor (birth -2 years). This stage is characterized by the ability of the child to differentiate self from objects, to recognize self as an agent of action and begin to act intentionally, and achieve objects permanence (realizes that things continue to exist even when no longer present to the sense). Second stage is Pre-operational (2-7 years). This stage is characterized by the ability of the child to learn using language and to represent objects by images and words, thinking is still egocentric (has difficulty taking the viewpoint of others), and to classify objects by a single feature (e.g. groups together all the red blocks regardless of shape or all).

Third stage is Concrete Operational (7-11 years). This stage is characterized by the ability of the child to think logically about objects and events, to achieve conservation of number (age 6), mass (age 7), and weight (age 9), and to classify objects according to several features and can order them in series along a single dimension such as size. Fourth stage is Formal Operational (11 years and up). This stage is characterized by the ability of the child to think logically about abstract propositions and test hypotheses systematically and to be concerned with the hypothetical, the future, and ideological problems.

Those stages of children's cognitive development is useful for this research to affirm that children need cognitive input which is appropriate for their age. The suitable cognitive input will help children to grow in accordance to their age and to avoid trauma in each stage of development. Trauma which happens in a single cognitive stage may affect the development on the next stage. The cognitive input in this research is in a form of audio visual information, specifically children short films.

\section{Mobile Movie Screening}

BIOSCIL's activity to bring films to children in remote area is known as mobile movie screening. Mobile movie screening (cinema mobile) is a mobile film distribution from one place to another, and it is more simple and practical. Thus, mobile movie screening can reach remote area with no cinemas (Erwantoro, 2014). This activity opens the access to information for the society so that the information gap among the society can be minimized. Besides, it can add more variety of media content for the targeted society.

In Indonesia, during Japanese occupancy, cinema or mobile movie screening was used by the Japanese government to spread their propaganda. At that moment, after Japan took over the power from Dutch in Indonesia, Japan enacted a new policy on film industry. One of the policies is regulation on film distribution through permanent cinema and mobile movie screening (Arief in Nugroho \& Herlina S., 2015, p. 67). Indonesian government during the New Order also implemented the same regulation. Film as propaganda and film to entertain were the government's main choices for the mobile movie screening.

However, it is different when the organizer of the mobile movie screening is a private organization or community, instead of government. Solar World Cinema, one of mobile movie screening activities that uses eco-friendly equipment, screens the movies which are rarely available in the public cinemas. This activity brings together the films and the audience in the unusual places. Not only screening movies, this activity also includes a workshop about cinematography. The mission of Solar World Cinema is to introduce the benefits of renewable energy, and also to equaling the access to alternative movie content (Solar World Cinema, 2016). 


\section{Film Classification}

Film classification is usually related to classification for films in big screen and television. Film classification is an effort to evaluate a film and to adjust its content according to its target audience. This classification is an alternative policy to censorship that usually used by government to limit certain contents of film, such as violence and sexuality. In Indonesia, during the New Order, censorship policy was applied even before the film is produced because a scenario must be approved by one government institution, namely Film Directorate of Department of Information (Sen, 2013, p. 113).

The atmosphere of censorship policy can be differentiated depends on who runs the policy. Some countries have handed-over the censorship policy and film classification to movie business association instead of government institution (Siregar, 2007, p. 19). Now, censorship and film classification in Indonesia is handled by Film Censorship Department (LSF), whose censorship policy is considered to be more dominant than its film classification. It gains criticism from film makers, film observers, and experts.

Film classification aims to give a guidance for the audience in choosing the film which appropriate for their age and character. In some countries, this classification is conducted by non-government institutions, for example British Board of Film Classification (BBFC) in the UK, The Motion Picture Association of America (MPAA) in the United States, and Freiwillige Selbstkontrolle der Filmwirtschaft (FSK) in Germany.

Two main objectives of BBFC classification guideline are, “"... to protect children and vulnerable adults from potentially harmful or otherwise unsuitable content; and to empower consumers, particularly parents and those with responsibility for children, to make informed viewing decisions." (Whitaker, 2014, p. 51). The making of this guideline includes public hearing and research. BBFC revises this classification guideline once in every 4-5 years to update in in accordance to the current development (Whitaker, 2014, p. 51).

The classification process conducted by BBFC takes seriously the public's opinion about things that should become consideration in a media content, including the necessary and unnecessary scenes to be watched by children in accordance to their age ranges. Thus, BBFC collaborates periodically with researchers to identify and consider the scenes that can be appeared in movie content. That research involves not only adults but also adolescence and children (Whitaker, 2014, p. 52).

Meanwhile, Covell (2017) explains the importance of a detail age grouping for children in considering the maturity of children in each age group. He states that children's involvement in the making of children film classification is very important. Moreover, film classification is, so far, a result of adults' point of view.

"The general worldwide trend in film classification, driven in part by the greater accessibility of films and other media in the home via television, home video, and online, is to have a larger number of age levels and classifications. This allows classifications to more closely match material to children's ages and stages of development, however it also places greater reliance on children's chronological age rather than a parental assessment of their maturity. This makes it even more desirable to have children participate in the classification process, so that the maturity of children of various ages is recognized and considered." (Covell, 2017)

Classification guideline, which is made by considering point of views from all the stakeholders, is an urgent needs. Especially in this digital era, where audio visual contents are available everywhere. This unavoidable condition needs to be overcame with a more comprehensive and specific classification guideline. Apparently, BIOSCIL also needs this classification for their mobile movie screening to serve as guidance in choosing the right short films for their unique audience. 


\section{Method}

This is a qualitative research, using Participatory Action Research (PAR). Action research involves an action researcher and community or organization members who are seeking to improve their situation (MacDonald, 2012, p. 36). This method is considered as suitable to help BIOSCIL, in improving their situation regarding their mobile movie screening for children. In this regards, PAR is used to help BIOSCIL in creating short films classification to be able to choose the most appropriate short film for their audience.

\section{Data Collecting Techniques}

Three data collecting techniques are used in this research; Focus Group Discussion (FGD), documentary, and participatory observation.

FGD is used to collect qualitative data from BIOSCIL and people who have experience working with children to understand their character, such as Non-Governmental Organization (NGO), psychologist, teachers, and also parents. Those people can also be considered as BIOSCIL's stakeholders. FGD was also used to collect the data from BIOSCIL and their relation with movie makers in Yogyakarta, to whom BIOSCIL depends on for their movie stocks.

Documents used in this research are short films, videos during the screenings, photos, and policies on media for children from other countries. Those documents help BIOSCIL to understand the character of the children, the existing policies, and the character of the films.

We were working with BIOSCIL for one year, and participated in almost each of their program especially mobile movie screenings. We volunteered, as well as observed, the children reactions during movie screenings, and also during the discussion after movie screenings.

\section{Result \& Discussion}

Data from FGD, which was attended by BIOSCIL founders, filmmakers in Yogyakarta, children related social organizations, and children film festival management, can be followed through the below explanation;

First, the classification of children film is unclear because the standard is yet available. Thus, the films which are permitted or not-permitted to be watched by children based on the range of ages, cannot be decided. However, there are some formulas and notes which can be adopted for the above classification, i.e. notes about educational film to introduce the variety of national cultures or educative films about violence, sexuality, languages, consumerism, or other dangerous and risky behaviours.

"The standard of children movies is unclear. Which movies can be watched by children and which are not... We are discussing about three issues, which are movies for children, movies by children and movies from children. Movies for children are still debatable and unclear because the format of children movies is confusing." (MRF, children movies festival management, FGD, 26 October 2017)

Second, film classification for children based on ages is very significant. It has different consideration for every range of ages so that children within that range will experience variety of learning. The characters within the film adjust truly with the different psychological and cognitive capabilities which are different in every range of ages. This becomes crucial note and be one of the principals in defining future children film.

"When it comes to talking about children range of age, it can be classified between 1-6 years old and 7-13 years old. Some international festivals have also divided to the matched age. For example, ages between 1-6 years old, films can be watched up to 10 minutes. To me, for 1-6 years old, 5 minutes is too long." (BKM, filmmaker, FGD, 26 October 2017) 
Third, our country has not got sufficient details of children film classification. We can refer to children film classification guidelines made by some countries in Europe and America however, those must be reconsidered because Indonesian film industry conditions are different with those countries. For example the small number of national children film which, up to this far, stood on spiritual issues to produce children film and of course, its funding.
"We have the National Committee for Human Rights, I used to refer to Swedish standards. Very strict and must be happy-ending. But then I thought that the problem of making classification is because of the experience. Then, we do not have to import classification. We do not want to get stuck on the classification which we have not experienced. Indonesia is different with the other countries in making children film. I am afraid, it will not be suitable." (EK, filmmaker, FGD, 26 October 2017)

The spirit and funding have become the main issues for the filmmakers. Some of them have already got their spirit however they have not been able to be properly funded, even though it does not weaken the hope of to emerge local children film. Some children foundations have started their collaboration with the filmmakers in effort to fund the production. Other parties such as the government and other festival managements have also the potential to widen this collaboration to improve the number of children film production. This will lead the related parties to concentrate more about the classification.

Meanwhile, FGD which involved BIOSCIL founders and their volunteers, children psychologist, organization concern on children named Saung Merapi, kindergarten and elementary teachers and parents aim to dig more information about the tendency of children characters and behaviours, especially when children are exposed to audio visuals. Some of these data from this FGD are to complete the data obtained from the previous FGD.

First, children are still amazed by film of superheroes. When the cinemas screens boomingly these kinds of films, children are taken by their parents to watch. Some parents do not understand that these films contain violence which are not supposed to be exposed to their children. This has become dilemma for parents where they want to take their children to enjoy the films however, the films conceive things which are not supposed to be exposed in front of their children. The children films which are existed need to work on children happiness without emerging improper actions which do not fit for their children at their age.

"Parents go watching film with their children without considering the children's sake. There are children films at the cinema but screened at night ... How do you explain to parents that what children have seen are recorded by them and someday those things will be done by them?” (NP, Psychologist, FGD, 16 November 2017)

Second, children store lots of events and memories. These memories will become one of the things which decide their future. One of the common examples is when children want to become Spiderman soon after they watch the film. These audio visuals will be memorized by the children where it gives the description of the sequence which is watched by the children, to decide their future. The imagination of profession and job which they will get in the future is formed by the visual symbols which previously emerged in front of them. This consideration needs to get special attention in deciding the proper film for the proper age group.

Third, supervising children when watching film. Parents need to pay attention to the meaning of the scene within the film so that parents can explain thoroughly of scenes being watched. At certain ages, children can watch films which can give new experience to them. Children can raise questions to those new experience and parents can explain and assist as well. However, parents as assistants are required to spend more time watching the film first. Meanwhile, our society is more likely to put film as the children's companion, which will then give parents possibility to do any other activities. However, at least, BIOSCIL always spends special time to assist children in watching film, so that children film classification can be used by the assistants as guidelines to discuss the content of the film when they first watching it. 
"The theme which is often raised is about adventure and bullying, which is close to our children problem. When there is no psychological violence, how can we raise the children issue within the film? When children see it in the film, children will understand that it is not good, of course with the assistance from the parents." (R, parent, FGD, 16 November 2017)

Fourth, the film's audio and visual technique should also be considered. Children within the certain range of ages can experience fear and trauma when exposed to shocking sound or picture or tense musical tone. This is also to be well-considered by the filmmakers when they intend to make films for children. Children enjoy films which have combination of stories which are not complex and the comfortable techniques in filming. It will make the children to easily understand the information and lessons within the content of the film.

"Do not use complex scenarios for children films. Children repeatedly watch a film to understand and comprehend the film they watch. Parents must be able to teach their children to express variety of emotions involved." (NP, Psychologist, FGD, 16 November 2017)

The search of documents has led the researcher to data about the film classification from Austrian Board of Media Classification (ABMC, n.d.). The document divides film classification in three different contexts, they are psychological development context, social policy context, and aesthetical quality. The summary of those three contexts in relation to children and media is as follow:

1. Psychological development context

- Children cannot differentiate between reality and fiction.

- Film which deserves positive feedback is a film which is possible for children to overcome the unknown situation, finding new things and able to obtain answers and knowledge at once through their senses.

- Children under 6 years old are vulnerable when left-alone without protection when facing tense and threats from the screen.

- Children need to watch complex scenarios to be solved quickly and give positive solution, especially with the emotion of loss.

- Children of 8 years old are able to differentiate between reality and fiction. They develop mechanics of distance to protect themselves from difficult situation.

- Some children between 11-14 years old can development "the love for fear". They can easily understand horror stories and even to expect more higher intense feeling. Younger children can also develop the particular sense. They need to voluntarily expose themselves to its frightening situation and need a role model to pass through this situation to experience that feeling.

2. Social policy context

- A good film can show what is right or wrong. Apart from that, a film must be able to give contribution to its viewers so that they can review their position.

3. Aesthetical quality

- The recommended topic is about children and teenagers in their daily activities, especially about family, friendship, love identity, animals, nature and nature conservations

- Special attention must be given to victims because empathy to victims can show someone else strong emotion.

- Happy ending is highly recommended.

This reference is combined with classification document from Freiwillige Selbskontrolle der Filmwirtschaft (FSK) Germany (FSK, n.d.) which clearly separate range of ages of children and teenagers, they are 0-6 years 
old, 6-12 years old, and 12 -16 years old. The document recommends proper and improper scenes for children and teenagers to fit to their age range. The summary of the document can be seen as follow:

1. Film for 0-6 years old

- Playing scenes can be presented

- A figure is needed

- Picture motion is not too fast (fair)

- The sound is not too loud

- Recommend avoiding dark scenes

- Simple conflict and quick resolution

2. Film for 6-12 years old

- Start to introduce emotional contents

- Conflict scenes is not too long

- Scenes can contain reality and fantasy

3. Film for $12-16$ years old

- It can start with topics of thriller, science fiction and action

- Recommend avoiding dangerous social behaviour, such as antisocial or destruction

Generally, the below points can also be considered:

- Avoid tense scenes

- Strengthen daily issues and can be resolved in short amount of time

- Dictions in dialogue, such as "sorry", "thank you" and "excuse me"

Meanwhile, the data from participative observation is obtained from the screening activities of five short films for children which repeatedly presented in front of the children by BIOSCIL in different locations. The participants of the screenings were the founders and volunteers of BIOSCIL, as well as lecturers and students of The Communication Study Program of The Faculty of Social and Political Sciences of Universitas Atma Jaya Yogyakarta. The early formulation has been set based on FGD and some supportive references which become guidelines of these screening activities. 
The two major attention of the screening are the content of the film and its technical in audio visual. The list of the category of content and technical which become the guidelines of observation on those films are as follow:

\begin{tabular}{lll}
\hline \multicolumn{1}{c}{ A. CONTENT } & \multicolumn{1}{c}{ B. TECHNIQUES } \\
\hline \multicolumn{1}{c}{$(-)$ negative } & Dark scene \\
\hline 2 & Discriminative scene and dialog & Loud audio/shocking \\
\hline 3 & $\begin{array}{l}\text { Anti-social and dangerous social behavior } \\
\text { that can be imitated by children }\end{array}$ & Too fast picture motion \\
\hline 4 & Coarse language, bullying, and mockery & \\
\hline 5 & Nudity, intimate relation, sexual activity & \\
\hline 6 & Scary/ threatening scene \\
\hline 7 & Violence (and sharp weapons use) \\
\hline & & \\
\hline 8 & Appreciative scene and dialog & \\
\hline 9 & $\begin{array}{l}\text { Introduction of professions and } \\
\text { aspirations }\end{array}$ \\
\hline 10 & Uncomplicated conflict and simple \\
& solution \\
\hline 11 & Figure that can be an example for children & \\
\hline 12 & Adventure/new experience for children \\
\hline 13 & Superhero \\
\hline 14 & Happy ending \\
\hline
\end{tabular}

The above list needs to be filled by the participants of screening to assess the films. In the process of assessment, the equation of perception between the participants keeps on happening until the film ends. One of the lecturers, appointed as moderator, then opens questions and discussion throughout the screening process. The different characteristics of the films have made the screening to need certain agreement to complete the classification guidelines.

One of the interesting findings from this screening is that some of the films which are commonly presented by BIOSCIL in front of the children contain dominantly negative content and technical so that they are improper to be presented in front the children under 12 years old. 
Generally, one of the sample results of the screening based on previous attempted classification guidelines is as follow:

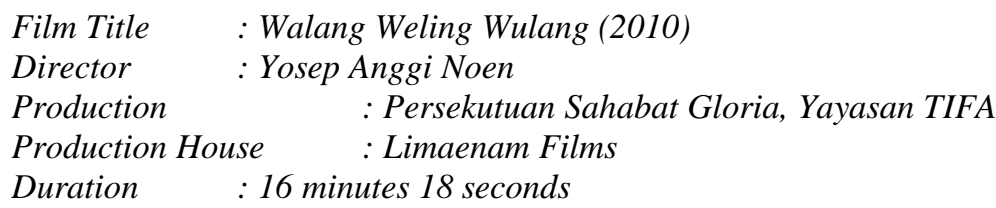

\begin{tabular}{|c|c|c|}
\hline NO & POINT & Recommendations \\
\hline A & CONTENT & \multirow{10}{*}{$\begin{array}{l}\text { The movie is recommended with } \\
\text { supervision in some scenes. } \\
\text { Notes: } \\
\text { - Supervision can be given during the } \\
\text { scene and dialog on religion and } \\
\text { diversity, to introducing and giving } \\
\text { understanding to children that } \\
\text { differences are for appreciated and } \\
\text { should not be a problem. } \\
\text { Supervision can also be given during } \\
\text { the scene when the actors go looking } \\
\text { for grasshoppers without a word to the } \\
\text { parents, far from home, up and down } \\
\text { the hills without any oversight from } \\
\text { adults. }\end{array}$} \\
\hline & $(-)$ & \\
\hline 1 & $\begin{array}{l}\text { Including a short scene of unfriendly behavior } \\
\text { and cheating that can be imitated by children. }\end{array}$ & \\
\hline 2 & Including a little bit of mockery & \\
\hline & $(+)$ & \\
\hline 3 & $\begin{array}{l}\text { Including appreciative scene and dialog about } \\
\text { religion and diversity }\end{array}$ & \\
\hline 4 & Uncomplicated conflict & \\
\hline 5 & $\begin{array}{l}\text { It has a figure that can be an example for } \\
\text { children }\end{array}$ & \\
\hline 6 & $\begin{array}{l}\text { Including new adventure for children, which is } \\
\text { looking for grasshoppers }\end{array}$ & \\
\hline 7 & Happy ending. & \\
\hline $\mathrm{B}$ & TECHNIQUES & \\
\hline 1 & Including dark scene but not terrifying & \\
\hline
\end{tabular}

The screening result of one of the films above can be an example for BIOSCIL in independently evaluating another films. It can be done by BIOSCIL together with related parties, such as volunteers, parents, teachers, and other movie screening organizers who work together with BIOSCIL. Finally, all children films screened by BIOSCIL will be classified with the criteria above and can be used by other parties who wants to conduct similar activity as BIOSCIL.

\section{Future scope of further research}

An interesting data emerged during this research, which is children's reception of the content of children short films. However, the data is ignored because it is beyond the focus of this research. Thus, the future research may focus on the children's reception of the audio visual content for children, which may be able to dig more about children's point of view in interpreting a film's content. The finding of the research might then be collaborated with this research findings to develop a more comprehensive classification guideline that involving children's point of view based on children's interests.

\section{Conclusion}

This is a participatory action research conducting in an independent organization called BIOSCIL whose main activity is mobile movie screening in remote areas in Yogyakarta. BIOSCIL faces problem in choosing the appropriate film for their unique audience in each screening. This research aims to help BIOSCIL creating a film classification which can be used to help them in deciding the right film in each screening. The result of this research is a guideline that can be used by BIOSCIL to classify their short films. The first screening using this guideline by BISOCIL's founders and volunteers, lecturers and students reveals that films with children as the main actors are not always suitable to be watched by children of all age and character (psychologically). The content of children films needs to be adjusted to children's psychology, which is differentiated based on age range. Supervision and assistance from parents or adults is highly recommended even when the film is considered as a child-friendly film. 


\section{Limitation}

This research has limitation in conceptual framework because most of the concepts used here are developed by America and European institutions. A further examination of those concepts is needed because the case of this research is in a local scope within the very diverse cultures of Indonesia.

\section{Suggestion}

This classification guideline can be used independently by BIOSCIL or other organization before conducting children short films screening. Other organization can apply this classification guideline to categorize local short films that are similar with the films that have been screened by BIOSCIL or have become the screening sample of this research.

\section{References}

ABMC. (n.d). Age rating of movies and similar image carriers by the Austrian youth media commission. Austrian Board of Media Classification. https://bildung.bmbwf.gv.at/schulen/service/jmk/jmk_agerating.pdf?5s8xmp

Covell, T. (2017). Children's participation rights in film classification systems. https://covell.ca/ijcr/

Erwantoro, H. (2014). Bioskop keliling: Peranannya dalam memasyarakatkan film nasional dari masa ke masa. Patanjala, 6(2), 285-300.

http://ejurnalpatanjala.kemdikbud.go.id/patanjala/index.php/patanjala/article/viewFile/200/151

Hananta, E. P. (2013). Konten kekerasan dalam film Indonesia anak terlaris tahun 2009-2011. Jurnal ekomunikasi, 1(1), 1-12. http://publication.petra.ac.id/index.php/ilmu-komunikasi/article/view/79

Filmindonesia.or.id. (2018). Daftar film berdasarkan genre "Anak-anak". http://filmindonesia.or.id/movie/title/list/genre/children\#.XNbBjY4zbIU

FSK. (n.d.). Alterseinstufungen und FSK-kennzeichen. Freiwillige Selbskontrolle der Filmwirtschaft. https://www.spio-fsk.de/?seitid=508\&tid=72

Joubish, M. F., \& Khurram, M. A. (2011). Cognitive Development in Jean Piaget's Work and its Implications for Teachers. World Applied Sciences Journal, 12(8), 1260-1265. https://pdfs.semanticscholar.org/4d5b/346602122c634fba7bb9535cd1db18018b48.pdf

MPAA. (2018). G is for golden: The MPAA film ratings at 50. The Motion Picture Association of America. https://www.mpaa.org/wp-content/uploads/2018/11/G-is-for-Golden.pdf

MacDonald, C. (2012). Understanding participatory action research: A qualitative research methodology option. Canadian Journal of Action Research, 13(2), 34-50. https://pdfs.semanticscholar.org/3b78/ecfe0b4a0a7591d2ea068c71e8ea320ff451.pdf

Nugroho, G. \& Herlina S., D. (2015). Krisis dan paradoks film Indonesia. Jakarta, Indonesia: Penerbit Buku Kompas.

Rosalia, I. (2018, Maret 31). Jumlah film ramah anak cuma sepersepuluh total film Indonesia. Beritagar.id. https://beritagar.id/artikel/seni-hiburan/jumlah-film-ramah-anak-cuma-sepersepuluh-total-film-indonesia

Sen, K. (2013). Sinema Indonesia membingkai orde baru. Translated by: Dyna Helina Suwarto. Yogyakarta, Indonesia: Rumah Sinema.

Siregar, A. (2007). Jalan ke media film: Persinggahan di ranah komunikasi-seni-kreatif. Yogyakarta, Indonesia: LP3Y.

Solar World Cinema. (2016). Solar world cinema: The solar powered mobile cinema brings unseen films to unusual places.

https://static1.squarespace.com/static/55224cb5e4b0abe69be80ec7/t/5810cdb6be6594a6e2add663/14774962535 87/Solar+World+Cinema+2016.pdf

Whitaker, L. (2014). The children's media yearbook 2014. London, UK: The Children's Media Foundation. https://www.thechildrensmediafoundation.org/wp-content/uploads/2014/07/cmf-yearbook-2014-pdf.pdf

Widyanita. (2016, July 26). Asing Minati Bioskop Indonesia. Katadata.co.id. https://katadata.co.id/infografik/2016/07/26/asing-minati-bioskop-indonesia 